\title{
The Moor of Venice: Critically Analysing Othello Based on Race, Colour, Gender as the Social Constructor, and the Facilitator to Kill Desdemona.
}

\section{Sneha Chakraborty}

Post Graduate Student, Department of Comparative Literature, Jadavpur University, Kolkata, West Bengal, India. Email id - chakrabortysneha1999@gmail.com | ORCID ID: 0000-0002-5350-0741

\section{Oly Saha}

Assistant Professor of English, M.U.C Women's College, Purba Bardhaman. PhD Candidate, Comparative Literature Department, Jadavpur University. Kolkata, West Bengal, India.

Email: olysaha_91@rediffmail.com | ORCID ID: 0000-0001-8658-1886

\begin{abstract}
After World War II, Shakespearean critics often found 'race' to be an incidental discourse in (c 0.1603). They were rooting for universal humanism and valour portrayed by the Moor of Venice, as their central point of evaluation. The paper would examine whether Othello's race and his cultural inheritance acted as a facilitator to kill Desdemona or it was the code of conduct (validated by the societal prescriptions) expected of a man in fifteenth-century England, concerning Renaissance ideals. This will be intertwined with examining the notions of ownership and honour in the play and how the 'motiveless malignity' affected the 'fate' of a woman. Do the tragic incidents happen due to the orchestrated plan by the shoddy opportunist Iago or the tenets of anxiety were always instilled in the mind of Othello even before his marriage with Desdemona? Would the events be different if he did not bear the essence of cultural exclusivity, of being a Moor, in his mind? Would the situation still turn out the way it did if Desdemona was a Moor? The paper would raise these questions and try to find the role of race, gender, and colour by accumulating substantial evidence from the play.
\end{abstract}

Keywords: Race, Valour, Fate, Social Construct, Inter-Personal Conflicts

\section{Introduction:}

Shakespeare could lay the human mind sole-naked without upholding any moralistic yardsticks. He described human nature as it is -it was and it will be not as others would like it to appear within their threshold of judgments. There is no trouble with the logical development of the characters in Shakespeare's plays; in his greatest tragedies, the reactions of the characters to every turn in the action are always intuitively right and their development as the play proceeds is felt to be inevitable. As we have seen in Othello and other plays, he stood up for the purity of morals 
through his plays but is human enough to recognize the man's inner dualities and conflicts. The characteristics of his characters develop as we follow him through success and failure, and we learn, before the play is over, to respect and admire him with all his weaknesses. Never does he do or say anything untrue to his nature, as Shakespeare conceived it to be. The Renaissance had shown the man his sins and called for looking at him from an 'anthropocentric worldview' without the ordainment of divine will. In Othello, HE upheld the power of the moral order. No inexorable fate broods over the actions of his men in ancient Greece. Shakespearean tragedy reaches its highest pitch of intensity. And yet it is a character that determines a man's destiny, for he is free to choose not only his thoughts but his words and deeds. The problems that centre on our common humanity were Shakespeare's constant theme and Othello is a pertinent reminder of that. The intersection of race, colour, women's rights, jealousy, honour, and the complexities of emotions of the characters are some of the tropes through which we can enter this world of extravagance and destruction. It also talks about the disastrous aftermath of 'fate' as a consequence of that. Lots of explorations were prevalent at the time when Othello was written, people from North American and Indian descents established their homes in England, which resulted in the cultural integration into the society. We could see the evidence of cultural integration, as well as estrangement, in Othello, as a crucial discourse in the play. Othello had always considered himself to be one of the 'cultural pluses' in Venice. As a stranger, he tried to gain social mobilization through his hard work and rose to the position as a general. However, the flickering concerns of not being connected to the roots of Venice by birth have always been visible in his dialogues. The task of serving a nation by being an outsider carries the added pressure of trying hard to retain the achieved respect. Othello is aware that he would be lost without his social position as general. There is the insecurity of losing that respect, along with a constant reminder of being different from other Venetians. This raises an important question about the deep-seated cultural baggage that could probe or accelerate his judgments during his actions. Through this paper, I want to prick deeper into the inner psychology of Othello and understand what must have gone through in Othello's chaotic mind before deciding to fulfill the draconian act of murder. Was Iago the real 'artist of crime' or just the facilitator of the already bestowed irremediable frustration and despair that eventually acted as a stimulus in the murder of Desdemona?

\section{Othello's Conflicts:}

Although Othello's valour and position as a general gained him social mobilization and respect, the element of cultural estrangement could be found from the inception. One of the mentions of his vulnerabilities could be found in his soliloquy: - 


\section{“Haply, for I am black, \\ And have not those soft parts of conversation \\ That chamber has, or I am declined \\ Into the vale of years, -yet that's not much}

She is gone, I am abused..." (Shakespeare, 107-109)

He is aware that he is different from others in society and can largely be distinguished from them based on colour but his love is fulfilled, as Desdemona chose him over other Venetians and it was his ultimate achievement. He talks about his storytelling skills that mesmerized Desdemona. However, his conclusion about her ('she is gone') shows how the manipulation by Iago in association with other self-imposed variants, slowly crept into his mind, taking advantage of his characteristic weakness as a 'cultural plus' and a 'coloured' protagonist.

The warning by Brabantio (Desdemona's father) held a significant place in his mind and was always present in his subconscious self that acted as a constant stimulus: -

"Look to her, Moor if thou hast eyes to see:

She has deceived her father, and may thee." (Shakespeare, 35)

From the history of Desdemona, we are aware that she has turned down the proposals by 'the curls and darlings' of the nation. She loved Othello, with his interior conflicts and complications and the real identity that he beholds. At the time, when Brabantio was completely sure that the Moor has willed Desdemona into his life with the help of witchcraft, he countered him by saying: -

She loved me for the dangers I had past

And I loved her that she did pity them. (Shakespeare, 31)

Therefore, Othello was pleased with the generosity of Desdemona being a good listener. He had identified her as the woman who would become an ideal choice for a homemaker. She is a beautiful person with ethical and moral boundaries that would enable her to become a perfect partner of a 'general' by sustaining the sanctity of his demeanour and position in society. There is an essence of hero-worshipping which can be witnessed instead of the indication of an equal partnership. Othello deduced that she loved him because of his heroic action in the past and his charismatic presence. We can deduce that marrying a Venetian person would not only add to his social status but also give him an extra edge against other Venetians who wanted to marry Desdemona but failed. There is a strong presence of cultural identification even while taking personal choices and the constant attempt to play with the identification to infuse a 'powerplay' in Othello. Despite introspecting about his own vulnerabilities and weaknesses, he never chose to bring them in front of his wife. The plausible reasons for that need to be taken into cognizance. It can be due to the gnawing social presence that was so deeply embedded in his mind that he could not express his heart out, even to his beloved partner. Maybe he was scared that his vulnerability would bring him down from the 
pedestal that he 'thinks' Desdemona puts him up to. He suppressed his inner insecurities and estrangements with the garb of the ultimate hero-like presence, without a seamless surface that would become impossible for anyone to fathom. His social image (infused with cultural isolation) became such a strong part of his life that showing vulnerabilities would mean falling from the selfconstructed, strong image that he had created over the years. He could never break the social wall and mingle with other Venetians without being reminded of his cultural exclusivity, which was evident in the play multiple times. However, Desdemona went against her father to marry Othello, as she was awestruck by 'Othello's visage in his mind'. (Shakespeare, 35) Therefore, she expressed her desire to be with this perceptive and complex man like a free-spirited individual seeking her love by fighting against the world. We can observe a conflict and a mis-identification situated at the very core of the relationship.

\title{
Desdemona as a Rebel and a Victim:
}

Fifteen-century England was inspired by the feminine attributes of the virgin Queen - Elizabeth I. She has become the epitome of virtues, love, grace, beauty, and was set as an ultimate idolized figure for ordinary women. The main essence of the playwrights was to develop their female characters by absorbing attributes from the Virgin Queen and uphold the purity and loyalty that she beholds. The women in fifteenth-century England did not have an individuality of their own and their identity was solely defined by the moralistic ideals and the ethical norms that she was supposed to maintain in the society as a 'partner', 'mother', or a 'child'? Desdemona is unique, as she somewhat breaks the shackles of societal obligation but also becomes an unaccounted victim of it. Though at the beginning of the play, Desdemona is seen to be an outspoken individual who made a strong stand by rejecting all the diligent suitors (as well as going against her father) to be with the love of her life. She opens her heart out to her father about her decision on the impossibility of turning away from the love of her life because her acquired education doesn't permit her to do so. She further adds that she has learned the essence of loyalty and the passion of love from her mother. Just like her mother showered him (Desdemona's father) with God-like respect and love, she does the same for the Moor: -

\author{
"My noble father, \\ I perceive here a divided duty. \\ To you, I am bound for life and education. \\ My life and education both do learn me \\ How to respect you. You are the lord of my duty, \\ I am hitherto your daughter. But here's my husband, \\ And so much duty, as my mother showed \\ To you, preferring you before her father, \\ So much I challenge that I may profess. (Shakespeare, 31)
}


She understands the fact that he has a different cultural inheritance, colour, and nationality and makes herself bound with the moralistic ground of loyalty and duty towards him. She shows the (expected) attributes of the 'moralistic' woman in fifteenth-century England as a 'dutiful' and 'loyal' companion. However, there is a unique dichotomy in her character, which further facilitates the concerns of Othello. He is aware that Desdemona was capable of speaking her mind, which was admirable until the time when Iago started manipulating their relationship. Her fearlessness as an attribute became a threat for Othello after the marriage, which made him realize that she is also capable of choosing another man over him. He had identified her with her free-spiritedness who is highly capable of making her own choices. However, after marriage, that similar attribute acted as a mode to ignite the suspicion of infidelity further. She always had a mind of her own, which permitted her to go against the societal dictates and marry a non-Venetian. It can be a magnum step for a woman at that time. Therefore, that mind can also facilitate disloyalty unfaithfulness towards her married partner when necessary and if required as assumed by Othello. It is the same attribute that initiated their marriage against the tidal waves of obstacles that came along the way in their relationship. This gives an insight into his mind, where similar characteristic traits change its position, from being the bearer of love and admiration to insecurity and discomfort. This shows Shakespeare as a propounder to understand man's struggles with temptations through their conflicting emotions, which carry universal fascination. Othello is creating unprecedented chaos within his mind by juxtaposing the present situation with past actions and is haunted by the thought of betrayal, dishonesty, and the gradual 'lack of control' over Desdemona. She was supposed to surrender her body, mind, and soul to her husband without restricting her individualistic choices. The most tragic part is that Desdemona abides by all these expected notions and has confined himself to the duty of Othello. However, the complexities of the human mind (renaissance, world?) and the psychology surrounding it are too fickle to compartmentalize, control or detect any immediate actions of individual. Desdemona fell for the human mind. However, the beauty of Shakespeare lies in its thriving need for contradicting characters that he portrays. Emilia (Iago's partner) has a pragmatic view towards marriage and the notion of loyalty associated with it. She is willing to have sex with other men if the circumstances turn out to be beneficial for her. She thinks infidelity to be a 'small sin' in the big world. Therefore, the idealism of Desdemona's loyalty is broken with this character, and the contradiction of behaviours with different shades arises. Emilia is logical enough to argue that she is willing to compromise if it benefits her or her husband in any way and deals with infidelity very casually. There cannot be any declaration of an absolute in the renaissance world, where a pre-determined regime would dictate an entire course of action of a play (like in the medieval world). There will always be contradictions where individuals will try to reach beyond the pre-defined boundaries and opt for alternatives. Shakespearean plays are the living and breathing examples of the beauty that sustains in, baffling the normative at the tenure of its discourse and the uncanny means to restore it at the end of the play. And, Othello is not an exception of the same! 


\section{Moor or not a Moor:}

It would be essential to look at a different argument when Othello was extremely pleased, as he was chosen, among all other Venetians, by Desdemona. His grateful, logical self was visible in Act III,

"...This is not to make me jealous

To say my wife is fair feeds well,

Love Company,

Is free of speech sings, plays, and dances well;

Where virtue is, these are more virtuous.

Not from mine own weak merits will I draw

The smallest of fears or doubts of her revolts;

For she had eyes and chose me..." (Shakespeare,103)

Therefore, he was aware that she loved him for a reason and stood firmly in that standpoint. What could be the plausible reasons for the sudden blur of judgments? One of the arguments can be that Othello never until that time, thought that Desdemona needed to be afraid of him. He trusted her but would never validate anyone else's presence in her life. When Iago orchestrated the plan, slyly forcing Cassio to reach out to Desdemona for help, he was tapping into an extremely sensitive place. Desdemona assures Cassio that she will help him by talking to Othello: "I'll watch him (Othello) tame and talk him out of patience..."(Shakespeare, 93) The woman who was supposed to behold her domesticity suddenly crossed her line in making judgments about the outside world. This shift and the transfer of power bewildered Othello when Desdemona asked him to forgive Cassio for his misconduct. She was overstepping into his boundaries and decision-making. This was facilitated by the warning given by Brabantio. His vulnerabilities reached their peak when the 'handkerchief' was stolen and acted as the chief confirmation of adultery. Desdemona provided Othello with a normal handkerchief, when asked, to not make him upset, but when Othello wanted to seek clarification about the 'special' handkerchief, she couldn't provide him with the same. He started explaining about the significance of the handkerchief (as a token from his mother) but she kept on asking for Cassio's forgiveness without paying due attention to it. It did ignite the flame that was already burning hard. The handkerchief just remained a silent observer, whereas its position shifted from the symbol of love to the trigger of revenge.

"He hath a person and a smooth dispose/To be suspected, framed to make a woman false." (Shakespeare, 43)

Two meditations happened in Othello's mind. First, he thought of being replaced by his wife with Cassio (someone who had a lower designation than him in society and was punished for misbehaviour) and someone who doesn't imbibe a 'coloured' presence like him. He was a 
handsome Florentine man who had an appeal for being a potential lover. His sudden gallantries and social courtesies often got misrecognized as a form of flattery among people. Therefore, he could become an effective pawn in Iago's plan. Though deeply committed to his duty, his openness and popularity among women folks buried the grave for Desdemona.

Secondly, Desdemona broke free from the confined duties of a partner and commented on Othello's course of action as his equal. The wife, who is supposed to be the subordinate of her husband, tried to make a dialog with him like a companion of equal measures. There was a huge distortion and imbalance in the power hierarchy and killing her would become the only way to bring stability to this power play. He dwelled in his extremities: the higher extravagant self and the lower culturalconscious estranged / vulnerable self. Two souls were dwelling in his body, which was at constant war with each other. His culture-conscious self-allowed him to make assumptions based on futile evidence and his extravagant self-showed him the path to bring stability to that disruption by killing his wife: -

"I will kill you and Love thee after". (Shakespeare, 189)

He wants to love the idealized Desdemona that he married. The woman would bow down to the social prescriptions and abide by the conventions set up by the partner without being a threat. According to him, Desdemona changed into a disloyal, seditious woman and the only way to bring the 'real' Desdemona back was by killing her. We get a glimpse of the complexities and the extremities of emotions in Othello's mind that made him perpetrate the fatal deed: -

“Even so my bloody thoughts with violent pace. Shall ne'er look back, ne' er ebb to humble love." (Shakespeare, 119)

What would happen if he was not a Moor? Would his cultural and colour-conscious self-take a back seat with the blooming of logical arguments? He would be more open-minded and aware of the customs and discourses of the people in that particular 'society' without being taken away by his conventional ideals. Brabantio's warning about his daughter would not prick him day in and out. He would have gone beyond his desperate need to prove his worth again and again. He wouldn't simply become the victim of his marvellous mind. He could also think about other plausible courses of action that could be executed without swaying away in rage and morose. Iago would find it difficult to take advantage of the cultural isolation while manipulating him and Othello would have many avenues to make an effective judgment without making it an act of impulsion. My arguments should not be taken as a way of validating the acts by Othello by making him the scapegoat of race and class. However, it acted as a major facilitator to his prospective judgments and there should be 
no doubts about it. He would never have felt less of himself because he was not a Venetian. The evidence of the handkerchief was to be disapproved as an act of absent-mindedness of beautiful women with no reason to be snubbed by the disparity of their complexion, which had otherwise played a significant role. This would happen even if Desdemona was a Moor. As her race and colour would come with their share of expectations and both of them would share a cultural resonance. And the readers would experience a colour-blind evaluation of their relationship. Othello could also experience a better connection with Desdemona and not try to own her because of 'internal insecurity' and 'inferiority complex. There would be lesser conflicts and clearer perspectives without any powerplay, adept manipulation, and the drive to take revenge for securing honour. They would be able to communicate with each other more freely, without any pre-occupied cultural baggage. Iago's presence as an intermediary would not have such a solidified impact on his mind. But even if there was a chance of cultural swapping between the protagonists, a deeper question needs to be analysed. We need to understand the futile lives of the women as a replaceable 'entity' and the beholder of honour. The fate of a woman was decided without even giving her a chance to explain her position. Iago, as an outsider could insinuate the conflicts so effectively, without any major hurdles. A husband could neither trust his wife nor keep his characteristic weakness and cultural difference in check. Was Othello so driven by his passion for revenge that he did not understand the gravity of his action? One can argue that Othello was written at a time when the identity of the women remained an extension of their spouses and by the moralistic yardsticks, they surrounded themselves with. However, Othello talks about a significant aspect of women's rights that is still relevant in today's time. We often hear cases of honour killings as a punishment for disloyalty or adultery in marriage. The actual position and the significance of women in society need to be addressed. The role of women in the society and their significance and honour, should not be judged or seen from the male-centric lens but from a more equal, individualistic way in society. The individual life choices and the acceptance of those choices should be rigidly incorporated in the law and order of the judiciary system. It would have been a wonderful place if Othello had thought about his decisions before jumping into the compulsive judgments. And it is equally important to understand the consequences that he suffered because of his action. Therefore, Shakespeare ends the love tragedy by identifying Othello both as the conqueror and the victim of his own mind. Finally, he got to know about Iago's manipulation and realized that he had mercilessly slaughtered the innocent Desdemona that broke him into pieces. He was bewildered and torn between betrayal and losing the love of his life based on delusional grounds. The subsequent self-guilt is resolved by slaughtering himself to death. Othello brings the final stability in his dual and conflicted self by finally killing himself: - "I kiss'd thee ere I killed thee: no way but this;" (Shakespeare, 211)

Through that action, he could finally be one with Desdemona. Therefore, it primarily becomes a love tragedy that has enabled and disabled the notions of various public arenas, including the martial world, but also how race, colour, and other constructs are discussed, valued, and devalued. 
Soft you, a word or two before you go.

Have done the state some service, and they know't.

No more of that. I pray you, in your letters,

When you shall these unlucky deeds relate,

Speak of me as I am. Nothing extenuate,

Nor set down aught in malice. Then must you speak

Of one that loved not wisely, but too well.

Of one not easily jealous, but being wrought, Perplexed in the extreme. Of one whose hand,

Like the base Indian, threw a pearl away

Richer than all his tribe. Of one whose subdued eyes. (Shakespeare, 209)

While speaking these words, he finally stabbed himself. He talks about his life and Desdemona. His guilt-ridden self comes into the forefront, where he realises that he couldn't be wise enough to know that Desdemona did not cheat on him. He also tries to justify his actions by speaking about the normalcy of "jealousy...' of one not easily jealous...." He further adds that anyone in the position would kill Desdemona. Here we get a glimpse of the clear binary being created by Othello to put his chaotic mind to ease. Although he feels sorry for murdering Desdemona, he is not quite 'apologetic' for the same. Therefore, normalizing the act of murder as a regular and prevalent discourse when faced with betrayal or disloyalty is the established and accepted cultural norm. Even if we eliminate the social situation, the authoritarian position of ownership bestowed upon one's partner is visible. Therefore, apart from social isolation, the inherited attributes of a man and his relationship with his wife, prescribed by the societal conventions, were never based on equal grounds with mere companionship. It was hierarchised, authoritarian, and supremely oppressive.

\section{Conclusion:}

We can talk about the tragedy of Othello as an indication of the failure of a man. This can be combined with race, colour, and gender as a social facilitator that had led to the gradual fall of Othello into the confinement of the secular world. However, we cannot judge the character regarding our temporal moralities: neither can we schematize the mysteries of redemption, which might at last exempt him from such judgments. It should be understood that it is imperative to understand the complexities of Othello as the Moor of Venice concerning his social status. His violent reaction, constant doubtfulness, skepticism is solely surrounded by his inner complexities, which whisper that 'he is not enough'. This constant dualism reflects the Renaissance man. He doubts his actions and is completely flawed. However, this doubtfulness doesn't turn his actions righteous. Othello becomes the sailor of his own fate, which is facilitated, nurtured, and later destroyed by him. This makes Othello, a tragedy which is the product of the change of the men's minds- "the Renaissance change-by which men came to feel separated from God; -by which, 
indeed, the idea of God receded from men's habitual certitudes and became no more and often less than an intellectual construction, a merely credible hypothesis, a Being remote and not certainly just or beneficent the Enemy" (Sen, 37). Othello becomes the victim which eventually leads to the murder of his beloved partner Desdemona. While she remained loyal to him, it was him who was swayed with the perpetual thought of being betrayed by her. However, no matter how much we look at the play from the lens of hierarchised social isolation and understand the pangs and ethos of Desdemona. It is essential to also look at it solely as a piece of art and a production of creative brilliance. Therefore, if Othello was not a Moor, the readers would be exempt from the Shakespearean mission that transcends the bounds of nations and becomes the property of humanity. We could never have the glimpse of a complex character and a tragic hero like Othello that successfully penetrated the secrets of humanity, as few characters have ever done, and interpret the secrets of them as few playwrights would ever do. One of the reasons for Shakespeare's worldwide appeal is the number and variety of characters that he developed. They include persons of all types who come from all walks of life. In Othello, Emilia's character provides an alternative to Desdemona's loyalty. Iago justified his manipulation. At the beginning of the play, he explains to Roderigo why he has decided to deceive Othello. He was upset with Cassio's promotion and wanted to seek revenge because Cassio was undeserving: "never set a squadron in the field" (Shakespeare, 5). No matter how much we talk about Iago's manipulation, it is Othello who finally decided to "put out the light" and murder Desdemona on her own choice. Therefore, every character has a shade and cannot be measured with the yardsticks of binaries. Shakespeare understood his characters so deeply and presented them so vividly that for any readers they have become more real than some of the living men about them. He was, to quote Dr. Johnson, "the poet that held up to his readers a faithful mirror of manners, and life. His characters are not modified by the customs of particular places...., they are the genuine progeny of common humanity, such as the world will always supply, and observation will always find" (Sen, 41). Therefore, Othello, by being a Moor, gave us one more reason to fall in love with the characters in the Shakespearean repertoire, which enabled us to "seek his works among primal necessities of life, demand them, crave them, and crave them as they do their daily bread". $(\underline{\operatorname{Sen}}, 41)$ and be equally enamoured by them.

\section{References}

Datta, Ketaki. "Othello: To Be A Moor Or Not To Be A Moor." Colonial And Post Colonial Shakespeares: Papers $\mathcal{E}$ Proceedings of The World Shakespeare Conference. Amitava Ray, Krishna Sen and Debnarayan Bandopadhyay. 1st ed. Calcutta: Avantgarde Press, 2000. 475-480. Print.

Shakespeare, William. "Othello: The Moor of Venice." Worldcat.org. N.p., 2005. Web. 16 Feb. 2021. <https://www.worldcat.org/title/othello-the-moor-of-venice/oclc/55682620>.

Garber, Marjorie B. Shakespeare After All. New York: Pantheon Books, 2004. Print. 
Sen, S. Julius Caesar, William Shakespeare, A Critical Evaluation. Revised by Dr G.S Mansukhani.New Delhi: Unique Publisher, 2014. Print

1Sneha Chakraborty is currently a Postgraduate student at the Department of Comparative Literature, Jadavpur University. Her research interests include Renaissance and Post Colonial Studies. She wants to pursue her research work in renaissance studies and try to evaluate the positioning of race, gender, class and the politics associated with the nature of representation in the narrative techniques.

${ }^{2}$ Oly Saha is currently pursuing a doctorate degree in the department of Comparative Literature, Jadavpur University. She is also working as an Assistant Professor in Maharajadhiraj Uday Chand Women\&\#39;s College in Purba Bardhaman. Her research is on Dalit Feminism and autobiographical politics. Her research interest area include Dalit Feminism, Indigeneity, Ecofeminism, Victorian and Renaissance literature. 